\title{
ECONOMIC EFFECT OF INTRODUCTION OF MODULAR TECHNOLOGY IN RAILWAY INDUSTRY
}

\author{
Artem BILOUS ${ }^{1}$, \\ Taras Shevchenko National University of Kyiv, Ukraine
}

\begin{abstract}
The purpose of the paper is to explore the current state of the railway engineering industry in the world, the problems of its development prospects, especially the introduction of the modular process technology and economic impact of its introduction. Methodology. The research is based on statistical information from public sources, which is used to confirm the veracity of the thesis put forward about the feasibility of further implementation of the principle of modularity in the railway engineering sector. Data was also obtained from the websites of manufacturers of railway equipment. Also, in the study of the issue, analytical articles on the economic development of the sector of railway engineering in the world were used. Results of the research showed that today, in transport engineering industry, in particular - in the railway engineering, there is a problem of inefficient implementation and use of technological developments, which are used in the manufacture of railway rolling stock. Many technical solutions are duplicated, leading to more time and financial costs. At the same time, there is no free access to information about existing technical solutions, which significantly slows down the development of rail transport. One of the main solutions to the problem is the use of modular technology in the design and manufacture of rolling stock. Leading global manufacturers have already begun to use the modules in the production of their rolling stock, but the technology is not yet sufficiently developed and finds its realization only in reducing the costs of production of rolling stock by specific manufacturers. The full benefits of the new technology have not yet been obtained by producers and operators. Thus, there is a considerable margin for the implementation of modular technology in the production of railway vehicles, which will result in further reducing both production costs and the costs of maintenance, operation and repair of rolling stock. Practical implications. The introduction of a modular system in the design, manufacture and operation of rolling stock will lead to a significant breakthrough in the development of the railway sector, reduce the cost of production and maintenance of railway equipment. Together with the inter-company exchange of technology and experience it will contribute to intensification of production and the development of new trends in the railway sector. Value/originality. These data show that the modular technology of the production construction has broad application prospects, while it does not require a significant capital investment. This approach can be applied to various types of rolling stock, as well as, potentially, to other industries. The achievements obtained in the railway sector will find their application in other fields of transport engineering.
\end{abstract}

Key words: railway engineering industry, rolling stock, modular technology, management, efficiency, new technologies.

JEL Classification: E23, L62, M11, 018

\section{Introduction}

Modern railway machine-building complex was formed in the twentieth century as an extremely complex system with its own laws of development. A large proportion of railway engineering among engineering industries makes it a significant in the national economy.

Development of railway engineering largely occurred spontaneously, which ultimately made it wasteful in expenditure of mater ials, energy and labor resources, negative impact on the environment, inertia to changing demands of society. And the further the railway engineering develops, the stronger its negative sides are.

In this regard to the problem of improving the industry aimed at improving its efficiency becomes paramount. At present, there is a distinguished individual tasks solution to this problem such as increased productivity, quality of rolling stock, reducing its material consumption, introduction of energy saving technologies, etc.

This approach to the problem can not radically change the existing situation in the railway industry and calls for

\footnotetext{
Corresponding author:

${ }^{1}$ Department of International Business, Institute of International Relations of Taras Shevchenko National University of Kyiv.

E-mail: bilousartem@ukr.net
} 
a new science and technology policy. It is necessary, firstly, to implement systematic approach to solving problems, and secondly, it must be resolved in a way that satisfies both the requirements of society and the needs of each company separately.

\section{General view of technical problems}

Carrying out such scientific and technical policy requires management of the development of railway engineering complex, for which it is necessary to introduce organizational rise in construction of engineering production. The solution can be administrative, but should be based on the results of in-depth study of the laws of engineering.

The task requires the understanding of common systemic shortcomings of modern engineering production. These include:

- duplication of technological development support (processes, machinery, equipment);

- excessive variety of technological software;

- loss of technological knowledge;

- incomplete use of the opportunities of technological support (process equipment and tooling);

- offensive obsolescence of technological equipment earlier terms of their physical deterioration.

Duplication of technological development software is as follows. Almost any unit of rolling stock comprises $50-70 \%$ of the general purpose parts such as shafts, axles, bushings, couplings, gears, covers, levers, strips, bodies and so on. Products also contain a lot of similar mechanisms and arrangements - spindle units, bearings, gearboxes, typical connection details. Hence, on average, each railway producing company within the general machine-building complex has total range of manufactured parts and assembly units for more than $50 \%$ very close to other companies and often identical in its design execution and technical requirements. As a result, for the manufacture of each of them, enterprises duplicate most of technological facilities. Ultimately, at almost all machine-building enterprises, the majority of engineering and technical specialists annually perform the same work, solve the same problems (Jacobs, F. Robert, Berry, William, Whybark, D. Clay, 2011).

Excessive diversity of technological support, which is growing steadily, is that different enterprises and even in different departments of one company for manufacturing similar products develop different technological support. This is due to the fact that companies differ in composition of technological equipment involved in the development of various professionals with different skill levels with no information on these developments. As a result, for the manufacture of each product (parts, assembly unit) hundreds of different types of processes and tooling can be developed, and often different technological equipment.

A large amount of work es performed, huge sums of money sometimes are spent, production process is being complicated, since number of new technological processes, equipment and tools is increasing. However, most of them are already known solution, and comparing them with the technical and economic characteristics shows that they differ little from each other in their effectiveness. Among this variety there are also innovative solutions that can give a great effect, but they drop out of sight in the mass solutions.

So, instead of focusing time of highly skilled staff on creating innovative technologies and techniques, there is a dispersion of forces, infinite duplication of work that entails unjustified increase in the variety of technological support (Kahn, Kenneth B., 2012).

Loss of technological knowledge is that due to imperfections in the organization of information on development, many decisions are unpublished, and among the huge flow of papers it is difficult, and sometimes impossible, to find the information you need to solve specific problems.

Especially the lack of information affects the manufacture of special components and assemblies requiring original technologies. Development and implementation of technologies usually associated with high labor costs, require skilled developers and long time for implementation.

After discontinuation of production, information about this technology is often inaccessible due to lack of papers or difficulties to find them in the huge flow of information. As a result, he experience, obtained costly, appears lost and not used by other companies.

Partial use of the opportunities of technological equipment is a common occurrence when all processing equipment, except equipment which is used in mass production, has to some extent redundant technological and technical capabilities at a particular workplace. The closer to the type of production of the single unit, the greater this excess is.

Redundancy of equipment capabilities is that at every moment of equipment its capabilities is used only partially. For example, universal lathes for $87 \%$ of their service life use only $20 \%$ of installed capacity of main drive, within $19 \%$ of their service life they use up to $75 \%$ and only within $1 \%$ over the life they use $100 \%$ of installed capacity. And the higher the versatility of equipment is, the greater the proportion of unused capacity appears. A similar pattern is observed with other technical and technological characteristics of technological equipment (Wilson, Lonnie, 2009).

At the same time, the presence of excess capacity leads to higher cost of equipment and maintenance costs. For example, the cost of a processing center reaches hundreds of thousands of dollars (Greasley, Andrew, 2009).

Appearance of obsolescence in technological equipment is earlier than terms of their physical deterioration and also widespread.

Indeed, in modern circumstances, a rapid change in the range of products applies to most of technological equipment, obsolescence of which occurs much faster than their physical deterioration. 
In this regard, there is a contradiction when, on the one hand, there is need to replace obsolete equipment, and on the other is the physical condition of equipment which allows to exploit it for a long time. In these circumstances, it is difficult to give up expensive equipment, especially the creation of new equipment associated with large labor and material costs and long term.

The above deficiencies have common, ambitious character and are just both for the entire machine production and directly for railway engineering.

All this leads to huge unproductive expenditure of labor, materials and energy and, if effective measures to eliminate these deficiencies are not taken, in the nearest future railway engineering could turn into a loss-making industry.

Therefore, modern railway engineering production is characterized by production of large numbers of the same or very close to each other such parts, machinery, devices that are included in various products at different manufacturings; significant duplication of technological preparation of production; unjustifiably huge variety of processes, equipment and facilities; huge annual renovation of physically worn technological facilities; low demand for technological equipment and technical capabilities.

\section{Introduction of modular technology}

The analysis of engineering production showed that, to minimize the above mentioned deficiencies, its radical restructuring is needed.

These objectives shall be addressed in conjunction with the system approach. Organizing principle shall firstly be entered into the building of the railway production, as that should be taken in the construction of modular parts of the production chain: product - manufacturing process technological system - workplace.

At the same time the accumulated experience of modularity creates favorable conditions for its widespread introduction in railway engineering. It is time to move from accidental use of modular construction principle in individual objects to implementation of a systematic approach when rolling stock and funds for its technological support shall be based on relevant modules combined into a single system. The implementation of this approach will give the effect of engineering production efficiency far above from what is available today.

Implementing of modular principle in the railway production from the view of system approach requires the development of the following:

- the substitution of rail production facility with many modules;

- general principles of the rolling stock production of modules and means of their technological support (processes, machinery, equipment);

- terminology providing;

- unification methods of product modules and means of technological support;

- methods for evaluation of the effectiveness of modular construction of products and means of technological support (Lehmann, Donald R., 2004).

Introduction of the modular principle starts with the same modular construction of vehicles. In this case, modules shall include such immutable elements that make up any items, for example, cabs, boggies, towing equipment, even bodies. In this case the modular principle becomes general in nature and will be effective for the entire engineering, and directly for the railway sub-sector.

This module of rolling stock shall be characterized with uniqueness, high resistance over time, described with minimum set of characteristics and a differ in a little nomenclature.

The uniqueness of module provides a unified description of any products regardless of their purpose, high stability over time ensures their long-term use, and a small set of features and a narrow range of typing helps to unify modules. Since the product's smallest element is a detail, it is logical to accept it as such a module. However, it is not possible because of the huge variety of constructive details, many characteristics describing them, so it should be found at a higher level.

Analysis of the details' execution their official functions allows to make an important conclusion that a detail performs it official appointment, mostly by combinations of surfaces and only in some cases with individual surfaces. Therefore, the detail can be represented as a set of combinations of surfaces (rarely, some surfaces) with the official designation. In this regard, the concept of the module surface of details was introduced, which refers to a combination of objectively existing surfaces (or individual surface), designed to jointly execute the appropriate utility function and provide details of last structural form, due to the requirements of operation and production.

\section{Modular design of modern locomotives}

The modular design of the rolling stock is a transient quick-access sections containing frames within which there is equipment of same purpose. Thus, it is possible to assemble a particular purpose locomotive of certain basic sections, in each case creating a customized design. Standard units are collected in one frame sections are formed into one group to perform servicing operations. At the initial stage of transition to modules, the traditional way of threaded connections is used. At a higher level, the inside equipment of the module will dock with quick basic ground connections (Jacobs, F. Robert, Berry, William, Whybark, D. Clay, 2011).

Modular design of a locomotive allows:

- increase productivity of locomotive to operate in different modes;

- reduce the cost of production of new locomotives, as well as maintenance and repair in depots and locomotive repair enterprises;

- unify modules for different types of locomotives;

- increase reliability, maintainability of equipment extend its life; 
- significantly decrease the quantity of staff;

- reduce the human factor in installation and verification of modules;

- introduce progressive methods of modern diagnostics of equipment of individual modules;

- reduce cycle of maintenance and repair, providing the opportunity to replace any module within minutes at the locomotives maintenance points;

- ensure simplicity and efficiency of modules transportation between the locomotive and repair depot;

- provide convenience and ease of assembly and installation of modules;

- provide aesthetic and ergonomic view of the engine room, remove protruding parts, pipelines and details of mechanisms;

- introduce new concepts of manipulators for basic operations of removing and installing modules in sections, providing the possibility of using unmanned technologies on major maintenance operations;

- ensure maximum operational readiness for operation of locomotives;

- create a universal design and technological solutions of modules for different types of locomotives depending on customer needs;

- apply full remote control of a locomotive (V.N.Balabyn, F. Vynkler, 2012).

These locomotives will differ with high reliability, adaptability, uniformity, have the necessary potential for further improvement. In addition, the modular design allows to change the configuration and connections within sections depending on the regional and environmental requirements, as well as operational work features.

The modular design principle can be considered as an example of an electric DC locomotive 2ES6 produced in Russia at the factory "Ural locomotives" under German technology in partnership with Siemens AG.

Placement of electric equipment in the electric locomotive 2ES6 is made under construction design principle, and all the space in body is conventionally divided into sections both in the vertical horizontal planes.

The technical result is the improvement of the use of interior body space, maximum use of load-bearing structures and frameworks of bogies and body as grounds for mounting of equipment, reducing the range of spare parts, equipment and devices for repairing locomotive in compliance with safety requirements.

The technical result is achieved with the equipment which is installed according to modular principle when building a body of locomotive, namely the maximum possible number of associations of machinery according to their functional parameters in the module, namely:

- The first module provides power to engines of the first bogie, namely is used to convert electrical energy of DC into 3-phase AC voltage with adjustable amplitude and frequency. IT includes traction transformer, network filter and cooling tower for cooling the equipment. Also, this module includes a device for cooling the traction motors of the first bogie.

- The second module provides power to the engines of the second bogie, and it is used to convert electrical energy of DC into 3-phase AC voltage adjustable amplitude and frequency, which includes traction transformer, network filter and cooling tower for cooling the equipment. Also, this module includes a device for cooling the traction motors of the second bogie.

- The third module is intended for operation of power and low-voltage equipment and to protect from electric overload and short circuit, which includes a cabinet with breakers, high voltage equipment cabinet, cabinet with low-voltage equipment, power converter control circuit block and auxiliary transformers.

- The fourth module is a source of compressed air on the electric locomotive, which includes two compressor units, consisting of the main and auxiliary compressors.

- The fifth module includes sanitary ware such as wash basin, bio-toilet.

\section{Conclusions}

Thus, the railway production on the principles of modular technology allows:

- to reduce for several times the complexity of technological preparation of production;

- reduce the cost of technological equipment by reducing its diversity and opportunities in the reallocation to reflow manufacturing of other products;

- reduce the number of adjustments, settings and the complexity of making the transition to new products;

- to increase productivity of processes in the manufacture of products in terms of production of different series through a combination of conversion, application of advanced methods of assembly and processing of details specific to multiseries production;

- in terms of the production of large series of products, to move quickly to production of new products by creating new technological means by arrangement of available modules;

- improvement the quality of manufactured products with building their processes with proven process modules etc.

\section{References}

Alstom Power signed an agreement on scientific and technical cooperation with Gdansk University of Technology.[Electronic resource]. - Retrieved from: http://www.alstom.com/press-centre/2012/4/alstompower-signed-angreement-on-scientific-and-technical-cooperation-with-gdask-university-of-technology/

Sokolenko, S. I. (1999). Hlobalizatsiya i ekonomika Ukrayiny. - K.: Lohos.

Bazrov, B.M. (2001). Modul'naya tekhnolohyya v mashynostroenyy. - M.: Mashynostroenye. 
Balabyn, V.N., Vynkler, F. (2012). Pryntsypy modul'nosty v proektyrovanyy sovremennykh avtonomnykh lokomotyvov. Nauka i transport, № 3.

Web-site of «Uralskie lokomotivy» plant. Retrieved from: http://ulkm.ru/produkciya/gruzovoj-elektrovoz-2es6/ Balabyn, V.N. (2009). Perspektyvy razvytyya teplovoznykh dyzeley novoho pokolenyya. Zh-l «Tyazheloe mashynostroenye.

Balabyn, V.N. (2012). Modul'naya konstruktsyya perspektyvnykh avtonomnykh lokomotyvov. Sovremennyy transport: infrastruktura, innovatsyy, intellektual'nye sistemy: Tr. Mezhdunarodnoy akademii transporta. SanktPeterburg.

Jacobs, F. Robert, Berry, William, Whybark, D. Clay. (2011). Manufacturing Planning and Control for Supply Chain Management. - McGraw-Hill Professional Publishing.

Lehmann, Donald R., Winer, Russell S. (2004). Product Management. - McGraw-Hill College.

Kahn, Kenneth B. (2012). Product Planning Essentials. - M.E. Sharpe.

Breyfogle, Forrest W., III, Breyfogle, Forrest W. (2003). Implementing Six Sigma Smarter Solutions Using Statistical Methods. - John Wiley \& Sons Inc.

Greasley, Andrew (2009). Operations Management. - Wiley \& Sons, Incorporated, John.

Wilson, Lonnie (2009). How To Implement Lean Manufacturing. - McGraw-Hill Professional Publishing.

Hill, Alex, Hill, Terry. Essential Operations Management. - Palgrave Macmillan, 2011.

\section{Артем БИлОУС}

\section{ЭКОНОМИЧЕСКИЙ ЭФФЕКТ ВНЕДРЕНИЯ МОДУЛЬНОЙ ТЕХНОЛОГИИ НА ЖЕЛЕЗНО- ДОРОЖНОМ ПРОИЗВОДСТВЕ}

Аннотация. Целью работы является исследование современного состояния отрасли железнодорожного машиностроения в мире, проблемы перспективы его развития, особенности внедрения модульной производственной технологии и экономический эффект от ее внедрения. Методика. Исследование основано на статистической информации из открытых источников, которая используется для подтверждения правдивости выдвинутого тезиса о целесообразности дальнейшего внедрения принципа модульности в отрасли железнодорожного машиностроения. Данные также были получены с веб-сайтов производителей железнодорожной техники. Также, при исследовании вопроса использовались аналитические экономические статьи по вопросам развития отрасли железнодорожного машиностроения в мире. Результаты исследования показали, что сегодня в отрасли транспортного машиностроения, и в частности - в железнодорожном машиностроении, существует проблема неэффективного внедрения и использования технических разработок, которые используются при производстве подвижного состава железных дорог. Многие технические решения дублируются, что приводит к большим временным и финансовым затратам. В то же время, отсутствует свободный доступ к информации о существующих технических решениях, что существенно замедляет развитие железнодорожного транспорта. Одним из основных вариантов решения возникшей проблемы является применение модульной технологии при проектировании и производстве подвижного состава. Ведущие мировые производители уже начали использовать модули в производстве своего подвижного состава, однако эта технология еще недостаточно развита и находит свою реализацию только в снижении издержек на производство подвижного состава конкретным производителем. Полной выгоды от новой технологии производители и эксплуатационники еще не получают. Таким образом, существует значительный запас по внедрению модульной технологии в производство железнодорожной техники, что приведет в дальнейшем к снижению как производственных затрат, так и затрат на содержание, эксплуатацию и ремонт подвижного состава. Практическое значение. Внедрение модульной системы в разработку, производство и эксплуатацию железнодорожного подвижного состава приведет к значительному рывку в развитии железнодорожной отрасли, удешевлению производства и обслуживания железнодорожной техники. Вместе с межфирмовым обменом технологиями и опытом это поспособствует активизации производства и освоения новых направлений в железнодорожной сфере. Значение/оригинальность. Полученные данные показывают, что модульная технология построения производства имеет широкие перспективы применения, при этом не требуя значительных капиталовложений. Данный подход может применяться к различным типам железнодорожного подвижного состава, а также, в перспективе, к другим отраслям промышленности. Наработки, полученные в железнодорожной отрасли найдут свое применение в других сферах транспортного машиностроения. 